\title{
The treatment of female stress urinary incontinence: an evidenced-based review
}

\author{
This article was published in the following Dove Press journal: \\ Open Access Journal of Urology \\ 16 June 2011 \\ Number of times this article has been viewed
}

\author{
Anne P Cameron \\ Allen McNeil Haraway \\ Department of Urology, Division \\ of Neurourology and Pelvic Floor \\ Reconstruction, University of \\ Michigan Health System, Ann Arbor, \\ MI, USA
}

Correspondence: Anne P Cameron Department of Urology, Division of Neurourology and Pelvic Floor Reconstruction, University of Michigan Health System, I 500 East Medical Center Drive, Ann Arbor, MI48I09, USA

Tel + I 7346/5 I262

Fax+I 7349369/27

Email annepell@med.umich.edu
Objective: To review the literature on the surgical and nonsurgical treatment options for stress urinary incontinence in women, focusing exclusively on randomized clinical trials and high quality meta-analyses.

Materials and methods: A computer-aided and manual search for published randomized controlled trials and high quality meta-analyses investigating both conservative and surgical treatment options for stress urinary incontinence. In the case of a treatment that is not studied in these formats large case series have been used.

Results: Articles were reviewed and the results summarized on pelvic floor physical therapy, pharmacotherapy, bulking agents, and surgery (open and minimally invasive).

Conclusion: There are numerous high quality studies in the literature. It can be difficult to make definitive conclusions on the most appropriate treatment options due to the variability in the outcomes used to define success in these articles. There is also a dire lack of studies evaluating and comparing the surgical options for patients with intrinsic sphincter deficiency.

Keywords: stress urinary incontinence, conservative and surgical treatment

\section{Introduction}

Urinary incontinence is defined as the involuntary loss of urine, which is objectively demonstrable, with such a degree of severity that it is a social or hygienic problem. ${ }^{1}$ It is estimated that the US alone spends US\$10 billion annually on therapeutic management, absenteeism, and disability related to urinary incontinence. Stress urinary incontinence (SUI) is the most common form of urinary incontinence with an estimated prevalence of $8 \%$ to $33 \% .^{2}$ Studies on the treatment of SUI are plagued by the lack of a universal definition of success. Some authors measure patient reported outcomes utilizing validated incontinence questionnaires, pad weights, or repeat urodynamics while others utilize simple improvement rates. The success rate is highly dependent on the definition of cure, hence one cannot compare results utilizing different outcomes. ${ }^{3}$ A literature search was performed in the PubMed database in February of 2011 using the keywords stress urinary incontinence, mid urethral sling, urethral bulking agents, pelvic floor muscle training, open surgical treatment for stress urinary incontinence, and behavioral therapy and weight loss. We focused almost exclusively on randomized clinical trials or high quality meta-analyses.

\section{Pelvic floor muscle training}

Pelvic floor muscle (PFM) training (two systematic reviews) ${ }^{2,4}$ is currently the accepted term, replacing Kegels and pelvic floor exercises. There are currently 24 RCTs in 
the literature. It is defined as "any program of repeated pelvic muscle exercises treated by a health care professional". ${ }^{4}$ This therapy is intended to improve the function and strength of the pelvic floor muscles. The patient is taught by digital vaginal examination to properly isolate or recruit the pubococcygeus without using other muscles. ${ }^{5}$ Physical therapists are well trained in this assessment and teaching of these exercises with the goal of strengthening and gaining control over the pelvic muscles. ${ }^{5}$

The common biofeedback techniques are different forms of manometry or electromyography used to measure vaginal muscle or external anal sphincter activity. In a systematic review, ${ }^{2} 24$ randomized controlled trials (RCTs) were identified, and 11 RCTs were of sufficient quality to be included. There is strong evidence to suggest that PFM exercises are effective in reducing the symptoms of SUI. They found no evidence that PFM exercises with biofeedback were more effective than pelvic muscle training alone (Table 1).

A large number of studies have investigated PFM training, but it is difficult to draw any conclusions for a number of reasons. There is great variation in the treatment regimens with different types of exercises, the number and frequency of exercises, the confirmation of the correct technique, and the use of biofeedback. The patient population often varies in the type and severity of incontinence.

\section{Summary}

Pelvic floor physical therapy is effective at reducing, but infrequently curing, SUI and the addition of biofeedback does not improve PFM exercise's effectiveness. Pelvic floor therapy regimens and the quality of instruction vary considerably hence it is best to refer to therapists with training in female pelvic floor therapy. Since this is a noninvasive and low-risk therapy it is reasonable to discuss this therapy with all women with SUI. Level 1 evidence.

\section{Weight loss}

In an RCT, Subak et al sought to determine whether a behavioral weight-reduction intervention for overweight and obese women with incontinence would result in greater reductions in the frequency of incontinence episodes at 6 months compared with a control group: 338 women participated in this trial with a BMI of $36 \pm 6$. There was an $8 \%$ reduction in weight in the study group compared to $1 \%$ in the control group. Both stress incontinence and urge incontinence were reduced more in the weight-loss group than in the control group, but there was a significant difference only in the stress urinary incontinence. A higher proportion of the intervention group than of the control group had a clinically relevant reduction of $70 \%$ or more in the frequency of all incontinence episodes $(P<0.001)$, stress-incontinence $(P=0.009)$, and urge-incontinence episodes $(P=0.04) .{ }^{6}$

This study was then extended to examine the longer term effects of the weight loss intervention. ${ }^{7,8}$ Outcome measures were collected at 12 and 18 months. Both groups continued to show decreases in weekly incontinence episode frequency from baseline, but differences between the groups were no longer significant at 18 months. The authors attributed this to a decrease in the difference of weight loss at 18 months, and an increasingly large reduction in incontinence in the control group. The improved stress urinary incontinence rates were sustained at 18 months in the treatment group. (Table 1).

\section{Summary}

Even a modest ( $8 \%$ body weight) amount of weight loss improves stress incontinence; unfortunately this weight loss is difficult to maintain and the effectiveness is abolished if the weight is regained. Given the other health benefits of maintaining a healthy weight, all women with SUI should be counseled about modest weight loss to improve SUI. Level 2 evidence.

\section{Pharmacotherapy for stress urinary incontinence}

Duloxetine $\left(\right.$ Cymbalta $^{\circledR}$, Eli Lilly, Indianapolis, IN) is a balanced and potent inhibitor of serotonin and norepinephrine reuptake. ${ }^{9}$ Its ability to stimulate pudendal motor neurons and increase striated urethral sphincter contractility is thought to be the basis for its efficacy in women with SUI. ${ }^{10}$

Dmochowski et al randomized 683 women, 22 to 84 years old, to duloxetine or placebo. There was a significant decrease in incontinence episode frequency with duloxetine compared with placebo ( $50 \%$ vs $27 \%, P<0.001)$ with comparably significant improvements in quality of life (11.0 vs $6.8, P<0.001)$. A greater majority of the placebo treated patients vs duloxetine treated subjects completed the study (87\% vs 69\%) (Table 1). ${ }^{11}$ The difference was primarily attributable to a higher rate of duloxetine early discontinuation related to side effects. Nausea was the most common side effect. ${ }^{12}$

Duloxetine has been approved for the treatment of stress urinary incontinence in Europe. Duloxetine is not US Food and Drug Administration (FDA) approved for stress urinary incontinence in the US. The manufacturer and patent holder 
Table I Summary of literature review findings

\begin{tabular}{|c|c|c|c|}
\hline Reference & Study type & Results & Summary \\
\hline \multicolumn{4}{|c|}{ Pelvic floor muscle therapy and weight loss } \\
\hline Berghmans and Hendriks ${ }^{2}$ & Systematic review & II RCT reviewed & $\begin{array}{l}\text { Pelvic floor muscle therapy (PFMT) } \\
\text { is effective for treatment of SUI. } \\
\text { Biofeedback no more effective than } \\
\text { PFMT alone. }\end{array}$ \\
\hline Subak et $\mathrm{al}^{8}$ & $\mathrm{RCT}$ & $\begin{array}{l}8 \% \text { weight loss in treatment group. } \\
P<0.05 \text { in improvement of SUI in } \\
\text { treatment group. }\end{array}$ & $\begin{array}{l}\text { Women with SUI should be counseled } \\
\text { about modest weight loss for treatment } \\
\text { of SUI. }\end{array}$ \\
\hline \multicolumn{4}{|l|}{ Pharmacotherapy } \\
\hline Dmochowski et al" & $\mathrm{RCT}$ & $\begin{array}{l}\text { Decrease in incontinence episode } \\
\text { frequency compared to placebo. } \\
50 \% \text { vs } 27 \%(P<0.00 \text { I }) \text {. }\end{array}$ & $\begin{array}{l}\text { SUl improved with duloxetine. Only } 69 \% \\
\text { completed the study due to side effects } \\
\text { (nausea) of the medication. }\end{array}$ \\
\hline \multicolumn{4}{|l|}{ Urethral bulking agents } \\
\hline Lee et $\mathrm{a}^{25}$ & RCT - fat vs placebo & $\begin{array}{l}\text { No difference in cure rates } 22 \% \text { vs } 21 \% \text {. } \\
\text { I death reported. }\end{array}$ & $\begin{array}{l}\text { Fat should not be used as a urethral } \\
\text { bulking agent. }\end{array}$ \\
\hline Corcos et $\mathrm{al}^{13}$ & $\begin{array}{l}\text { RCT - collagen vs open } \\
\text { surgery }\end{array}$ & $\begin{array}{l}\text { I } 33 \text { females. I2-month success rate after } \\
\text { collagen }(53 \%) \text { and surgery }(72 \%) \text {. }\end{array}$ & $\begin{array}{l}\text { Collagen is a good alternative for patients } \\
\text { unable to tolerate surgery. }\end{array}$ \\
\hline Ghoniem et $\mathrm{al}^{27}$ & $\begin{array}{l}\text { RCT - Macroplastique vs } \\
\text { Contigen }\end{array}$ & $\begin{array}{l}247 \text { females. At } 12 \text { months, } 61 \% \\
\text { (Macroplastique) and } 48 \% \text { (Contigen) } \\
\text { had improved I Stamey grade. }\end{array}$ & $\begin{array}{l}\text { Macroplastique was statistically more } \\
\text { effective than Contigen. }\end{array}$ \\
\hline Mayer et a ${ }^{28}$ & RCT - Coaptite vs Contigen & $\begin{array}{l}296 \text { females. } 63 \% \text { (Coaptite) vs } \\
57 \% \text { (Contigen) improved I Stamey } \\
\text { grade or better. }\end{array}$ & $\begin{array}{l}\text { Both materials are well tolerated. } \\
\text { Coaptite required less material. }\end{array}$ \\
\hline terMeulen et al ${ }^{34}$ & Systematic review & 2 RCT reviewed (Macroplastique). & $\begin{array}{l}\text { More RCTs are necessary to establish } \\
\text { the efficacy of Macroplastique. }\end{array}$ \\
\hline Keegan et $\mathrm{al}^{26}$ & Cochrane database review & I2 RCT reviewed. & $\begin{array}{l}\text { The trials were small and of moderate } \\
\text { quality. Pending further evidence, injection } \\
\text { therapy may represent a useful option. }\end{array}$ \\
\hline \multicolumn{4}{|l|}{ Open surgery for SUI } \\
\hline Albo et $\mathrm{al}^{43}$ & RCT - Burch vs fascial sling & $\begin{array}{l}655 \text { females. Overall category of } \\
\text { success }(47 \% \text { vs } 38 \%, P=0.0 \mathrm{I}) \\
\text { and the category specific to stress } \\
\text { incontinence }(66 \% \text { vs } 49 \% \text {, } \\
P<0.00 \text { I) favored the fascial sling. }\end{array}$ & $\begin{array}{l}\text { Success rates were higher with a fascial } \\
\text { sling. More UTIs, difficulty voiding, and } \\
\text { postop urge incontinence were } \\
\text { associated with the fascial sling. }\end{array}$ \\
\hline Ward and Hilton ${ }^{44}$ & $\begin{array}{l}\text { RCT - TVT vs Burch } \\
\text { colposuspension }\end{array}$ & $\begin{array}{l}\text { No significant difference found between } \\
\text { cure rates. }\end{array}$ & $\begin{array}{l}\text { Cure rate was the same. Operative } \\
\text { time, duration of hospital stay, return } \\
\text { to normal activities were longer after } \\
\text { colposuspension. }\end{array}$ \\
\hline Novara et al ${ }^{54}$ & Systematic review & $\begin{array}{l}\text { Colposuspension vs PV sling vs mid } \\
\text { urethral tape. } 39 \text { RCTs reviewed. }\end{array}$ & $\begin{array}{l}\text { Retropubic tape had higher continence } \\
\text { rates than colposuspension. PV sling } \\
\text { similar to colposuspension. }\end{array}$ \\
\hline Glazener and Cooper ${ }^{46}$ & Cochrane database review & Bladder neck needle suspensions. & \\
\hline Dean et a ${ }^{148}$ & Cochrane database review & Laparoscopic colposuspension. & $\begin{array}{l}\text { Comparable to an open approach. Faster } \\
\text { recovery. Vaginal sling procedures offer } \\
\text { even greater benefits of minimally invasive } \\
\text { surgery and have better outcomes. }\end{array}$ \\
\hline Lapitan et $\mathrm{al}^{49}$ & Cochrane database review & Open retropubic colposuspension. & $\begin{array}{l}\text { Effective modality in the long-term. } \\
\text { Mid-urethral slings comparable in the } \\
\text { short-term. }\end{array}$ \\
\hline \multicolumn{4}{|l|}{ Synthetic slings } \\
\hline Liapis et al ${ }^{63}$ & $\mathrm{RCT}$ & $\begin{array}{l}\text { I } 14 \text { patients available at } \mathrm{f} / \mathrm{u} \\
\text { at } 12 \text { months. }\end{array}$ & $\begin{array}{l}\text { Objective cure rate was } 87 \% \text { for the } \\
\text { TVT-O and } 90 \% \text { for the monarch sling. }\end{array}$ \\
\hline Abdel-Fattah et a ${ }^{64}$ & $\begin{array}{l}\text { RCT - TOT “outside-in" vs } \\
\text { "inside-out" }\end{array}$ & $\begin{array}{l}34 \text { I women were randomized. } \\
\text { Success rates were } 85 \% \text { (“outside-in”) } \\
\text { and } 80 \% \text { at } 2 \text {-year follow-up. }\end{array}$ & $\begin{array}{l}\text { No significant differences in the objective } \\
\text { cure rates and patient reported success } \\
\text { rates between "outside-in" and "inside- } \\
\text { out" TOT. }\end{array}$ \\
\hline
\end{tabular}

(Continued) 
Table I (Continued)

\begin{tabular}{|c|c|c|c|}
\hline Reference & Study type & Results & Summary \\
\hline Latthe et $\mathrm{al}^{67}$ & Systematic review & $\begin{array}{l}\text { I I RCT comparing TOT or TVT-O vs } \\
\text { TVT were reviewed. }\end{array}$ & $\begin{array}{l}\text { Subjective cure rate between TVT-O and } \\
\text { TOT were no better than TVT. } \\
\text { Bladder injury/voiding dysfunction more } \\
\text { prevalent with TVT. Groin pain/erosion } \\
\text { with TOT. }\end{array}$ \\
\hline Richter et $\mathrm{al}^{70}$ & $\begin{array}{l}\text { Randomized equivalence } \\
\text { trial comparing retropubic } \\
\text { vs transobturator slings. }\end{array}$ & $\begin{array}{l}565(94.6 \%) \text { completed the } 12 \text {-month } \\
\text { assessment. Objectively assessed } \\
\text { treatment success were } 80.8 \% \text { in the } \\
\text { retropubic-sling group and } 77.7 \% \text { in the } \\
\text { transobturator-sling group. Subjectively } \\
\text { assessed successes were } 62.2 \% \text { and } \\
55.8 \% \text {, respectively. }\end{array}$ & $\begin{array}{l}\text { Objectively assessed successes were } \\
\text { equivalent. Subjective successes were } \\
\text { similar but not equivalent. Voiding } \\
\text { dysfunction more common with } \\
\text { retropubic sling. Neurologic symptoms } \\
\text { more common with TOT. }\end{array}$ \\
\hline Schierlitz et $\mathrm{al}^{71}$ & $\mathrm{RCT}$ & $\begin{array}{l}\text { I } 4 \text { of } 67(2 \text { I\%) had urodynamic } \\
\text { stress incontinence in the TVT group } \\
\text { compared with } 32 \text { of } 7 \text { I }(45 \%) \text { in the } \\
\text { transobturator tape group }(P=0.004) \text {, } \\
\text { with nine women in the transobturator } \\
\text { tape group having repeat sling surgery } \\
\text { compared with none in the } \\
\text { TVT group. }\end{array}$ & $\begin{array}{l}\text { Retropubic sling is a more effective } \\
\text { operation than the transobturator tape in } \\
\text { women with ISD. }\end{array}$ \\
\hline Kennelly et $\mathrm{al}^{72}$ & $\begin{array}{l}\text { Multicenter prospective } \\
\text { evaluation }\end{array}$ & $\begin{array}{l}\text { I } 57 \text { patients available for I-year analysis. } \\
90.6 \% \text { had a negative cough stress test } \\
\text { and } 84.5 \% \text { had a I-hour pad weight test } \\
\text { less than I g at I } 2 \text { months. }\end{array}$ & $\begin{array}{l}\text { Miniarc sling demonstrated excellent } \\
\text { patient tolerability with minimal pain, } \\
\text { early return to normal activity and low } \\
\text { morbidity. }\end{array}$ \\
\hline Ogah et $\mathrm{al}^{59}$ & $\begin{array}{l}\text { Cochrane database } \\
\text { review }\end{array}$ & $\begin{array}{l}62 \text { trials reviewed. The quality of } \\
\text { evidence was moderate for most trials. }\end{array}$ & $\begin{array}{l}\text { As effective as traditional suburethral } \\
\text { slings, open retropubic } \\
\text { colposuspension in the short-term. } \\
\text { Objective cure rate increased with } \\
\text { retropubic tapes. More } \\
\text { complications associated with } \\
\text { retropubic tapes. }\end{array}$ \\
\hline
\end{tabular}

Abbreviations: RCT, randomized control trial; SUI, stress urinary incontinence; TVT, tension free vaginal tape; TVT-O, TVT obturator; TOT, transobturatortape; ISD, intrinsic sphincter deficiency.

of duloxetine, Eli Lilly, withdrew their FDA application for a new indication of stress urinary incontinence. No other medical therapies have been studied in RCTs to date.

\section{Summary}

Currently there is still no good pharmacological therapy available for the treatment of stress urinary incontinence in women. Level 2 evidence.

\section{Urethral bulking agents}

Urethral bulking agents have the advantage of being performed in the clinic setting with no need for general or regional anesthetic and minimal risk making them ideal for use in those individuals who are poor surgical candidates due to comorbidities. ${ }^{13}$ They are suitable for women with intrinsic sphincter deficiency since they function by increasing the power of the sphincter mechanism and act as a central filler volume increasing the length of muscle fibers. ${ }^{14}$ Injectable therapies are minimally invasive but have been shown to be $19 \%$ less successful than open surgical approaches to cure SUI in one trial. Patient satisfaction and quality of life were similarly improved with an increase in number and severity of complications after open surgery (Table 1). ${ }^{13-16}$ However, their success has been reported to be much worse than this when Macroplastique ${ }^{\circledR}$ (Uroplasty, Minnetonka, $\mathrm{MN}$ ) and pubovaginal sling were compared with objective cure rates at 6 months being $81 \%$ after the sling and only $9 \%$ after Macroplastique $(P<0.0001) .{ }^{17}$ Other limitations of injectable therapies include their biodegradability and need for retreatment, particularly with collagen (Contigen ${ }^{\circledR}$, CRBard, Murray Hill, NJ). The unknown long-term risk of urethral complications as well as the possibility of distant migration and antigenicity of these substances is also of great concern. Suspicion among medical providers about the true safety of injectable agents is not unfounded. Teflon urethral injections in animal studies confirmed distant migration and granulomatous reaction in the lymph nodes, lung, and brain. ${ }^{18} \mathrm{~A}$ randomized controlled trial failed to show any 
increased risk of complications with Uryx ${ }^{\circledR 19}$ which was subsequently FDA approved, but later withdrawn from the market due to $37 \%$ urethral erosions in this case series. ${ }^{20}$ Other agents such as Zuidex ${ }^{\circledR}$ have an unacceptably high rate of urethral complications such as pseudo abscess and were less effective than the reference standard of collagen in $\mathrm{RCT}^{21-23}$

A European trial comparing autologous myoblast and fibroblasts mixed with collagen compared with collagen alone had very high 12-month continence rates, but was retracted due to questionable research practices. ${ }^{24}$ Other autologous materials, such as fat, have been used in the past and will be described below (Table 1). ${ }^{25}$

A Cochrane review ${ }^{26}$ on urethral bulking agents in 2007 included twelvetrials. The data were found to be an unsatisfactory base for practice recommendations, but four higher quality RCT have been published since this review and are included here (Table 1). ${ }^{16,23,25,27}$

\section{Fat (I RCT)}

One small RCT compared autologous fat to normal saline (placebo) in 68 women. There was no difference in the improved/cure rate between these two groups $(22.2 \%$ vs $20.7 \%$ respectively) at 3 months and one death occurred from a fat embolism. ${ }^{25}$ Fat should not be used as a bulking agent.

\section{Collagen (3 RCTs)}

Collagen $\left(\right.$ Contigen $\left.^{\circledR}\right)$ has served as the standard by which all other injectables are compared and unfortunately will soon be discontinued by its only manufacturer. It was FDA approved as a urethral bulking agent in 1993 and has been well studied with many large case series and had been used as the comparison group in several RCTs ${ }^{13,26,28,29}$ with very few complications other than irritative voiding symptoms and temporary retention (Table 1).

Its major drawback is the need for a collagen skin test 28 days prior to therapy to rule out allergic reaction (4\%) and its effectiveness has been shown to deteriorate over time due to resorption necessitating repeat injections. ${ }^{30}$

One RCT compared collagen injections to open surgery (fascial sling, Burch, or needle suspension) for SUI in 133 women. ${ }^{13}$ At 1 year, $32.8 \%$ of patients were not satisfied with their procedure compared with $20.4 \%$ in the open surgery group. There were more urological side effects and pain in the open surgery group. Success defined as a negative 24-hour pad weight was significantly higher in the surgery group $(72.2 \%$ vs $53.1 \% P=0.01)$.
Although never studied in RCT there is convincing evidence that there is a very high rate $(93 \%$ improved or cured) of success with collagen as a salvage procedure after a failed suspension or repair ${ }^{31}$ and this improvement is long lasting in this particular population even with a single collagen injection. ${ }^{29}$

\section{Coaptite (I RCT)}

Coaptite $^{\circledR}$ (Boston Scientific, Natick, MA) is spherical calcium hydroxylapatite (principal constituent of bones and teeth) suspended in a carboxymethly cellulose gel carrier. ${ }^{32}$ In animal experiments fibroblast infiltration occurs as the gel carrier degrades over months and heterotopic ossification does not occur. The substance is more viscous than collagen, but can be injected with a 21-gauge needle. An RCT with 296 women with intrinsic sphincter deficiency (ISD) and without urethral hyper mobility compared Coaptite ${ }^{\circledR}$ to bovine collagen. At 1 year, $63.5 \%$ of the Coaptite patients and $57.0 \%$ of the collagen patients $(P=0.34)$ had at least one Stamey grade of improvement in incontinence $39 \%$ and $37 \%$ cure respectively $P=0.78$ ) which confirmed the noninferiority of coaptite. ${ }^{27} 55 \%$ less volume of material was injected with the Coaptite group and the material is not felt to be biodegradable. There was no permanent retention with equivalent temporary retention rates ( $41 \%$ vs $33 \%)$, but an increase in urgency incontinence following collagen injection $(5.7 \%$ vs $12 \% ; P<0.05)$. One patient has a vaginal extrusion of the Coaptite believed to be due to prolonged tissue pressure effect and one patient had dissection of the material under the trigone with no sequelae. There are recent published reports of large urethral mucosa prolapses occurring following injection of this material that required surgical intervention. ${ }^{33}$

\section{Macroplastique}

This is the most studied of the synthetic injectable agents (four RCTs and one systematic review). ${ }^{34-36}$ It is composed of solid polydimethylsiloxane suspended in inert gel. The systematic review could not recommend Macroplastique due to insufficient evidence, ${ }^{35}$ but three RCTs have been published since that time (Table 1). ${ }^{16,17,34}$

In women with urethral hypermobility and SUI, Macroplastique (24 women) had higher cure and improvement rate of $70.8 \%$ compared with a pelvic floor exercise program (21 women) $28.5 \%(P=0.029)$. This study did not follow both groups past 3 months and with small treatment groups few definitive conclusions can be drawn. ${ }^{16}$ A large multicenter RCT comparing Macroplastique with collagen in 247 women with ISD showed improvement in one Stamey grade in $61.5 \%$ 
of the Macroplastique (36.9\% cure) and $48 \%$ of collagen (24.8\% cure) at 12 months $(P, 0.05)$ with similar adverse events (Table 1). ${ }^{26}$ This group followed those who were cured with Macroplastique for 2 years and found $84 \%$ sustained success. ${ }^{35}$

\section{Permacol (I RCT)}

Permacol $^{\circledR}$ (Covidien Surgical, Mansfield, MA) is porcine dermal collagen that is not reconstituted like Contigen ${ }^{\circledR}$ (bovine collagen), but maintains its original 3-dimensional form and is biocompatible since it is of porcine origin with no skin test required..$^{36} \mathrm{~A}$ small RCT with 50 women compared this material injected periurethrally to Macroplastique injected transurethrally. ${ }^{36}$ There were similar minor adverse events, but no statistical difference in incontinence at 6 months. Higher powered studies with longer follow-up are required before any recommendations can be made for this product.

\section{Durasphere $^{\circledR}$ (2 RCT)}

Durasphere $^{\circledR}$ (Coloplast, Denmark) is composed of pyrolitic carbon-coated zirconium oxide bead suspended in a $2.8 \%$ glucan (a polysaccharide used in wound healing) carrier gel. ${ }^{37,38}$ It was found to be equally effective as collagen in 355 women with stress incontinence and leak points less than $90 \mathrm{~cm} \mathrm{H}_{2} \mathrm{O}$ with improvements in one Stamey incontinence grade at 1 year from baseline in $66.1 \%$ of the Durasphere and $65.8 \%$ of the collagen $(P=0.162)$ treated women. An equal number of injections was required (1.69 vs 1.55$)$ and the adverse events were similar for both groups with a slight increase in acute retention lasting less than 7 days and urgency in the Durasphere group. This trial showed no evidence of antigenicity and pelvic X-rays taken postprocedure and at 1 and 2 years follow-up showed no migration of particles. ${ }^{37}$

Significant particle migration into the urethral mucosa and both regional and distant lymph nodes has been observed in nonrandomized trials and high pressure injection is believed to be the cause..$^{39,40}$ Durasphere in its original formulation (particle size 200-550 $\mu \mathrm{m}$ ) was difficult to inject due to viscosity and required high pressures, but recently Durasphere-EXP (95-200 $\mu \mathrm{m})$ has been introduced to resolve this issue. To avoid particle migration the minimum size should be $>80 \mu \mathrm{m} .{ }^{18}$ Periurethral masses have also been reported following Durasphere treatment requiring surgical drainage or excision in $2.9 \% .{ }^{40}$

\section{Stem cell therapy}

Stem cell therapy is not FDA approved, but there are promising results for stem cells injected alone without collagen in pilot studies performed in North America. ${ }^{41}$

\section{Summary}

With the disappearance of collagen, Macroplastique and Coaptite have emerged as safe and effective bulking agents with no antigenicity or distant migration. Macroplastique can be difficult to inject and requires a specialized instrument, but has the most data on its safety. The new Durasphere has not been evaluated in RCT. Level 1 evidence.

\section{Traditional open surgical approaches}

Recently, several large RCT have been performed to evaluate the success of open slings and enough information has been accrued to perform adequate Cochrane reviews of the various techniques (Table 1). ${ }^{42-44}$

\section{Artificial urinary sphincter (AUS) (0 RCT)}

This is frequently used in the male population for the treatment of SUI, however, there are to date only case series to describe its use in the female population. ${ }^{45}$ The surgical technique requiring bladder neck placement, the high risk of erosion, and the need for revisions have limited its use and study. Currently evidence is insufficient to make recommendations.

\section{Anterior repair (I0 RCTs, I systematic review)}

This is a purely vaginal approach to SUI that aims to correct urethral hypermobility. The vaginal mucosa overlying the urethra is dissected and sutures are placed in the periurethral tissue and pubocervical fascia to support and elevate the bladder neck (Kelly plication). This is typically done in conjunction with a cystocele repair. A thorough Cochrane review was done on this intervention and was updated in 2009. ${ }^{46}$ Ten trials were reviewed including 385 women who had an anterior repair for SUI. Compared with retropubic suspension, failure rates were doubled in the anterior repair groups at 1 year (29\% vs 14\% in six trials), between 1 and 5 years (38\% vs $17 \%$ in six trials) and longer than 5 years ( $38 \%$ vs $21 \%$ in four trials). There were few differences in the urological and overall morbidity. With these poor results and no advantage to this procedure it has almost been abandoned as a primary treatment for SUI.

\section{Bladder neck needle suspensions (I0 RCTs, I systematic review)}

These are performed by passing a suture on a needle passer from the vagina to the anterior abdominal fascia via an abdominal or vaginal approach. The three basic techniques are: Pereyra, Raz, and Stamey and each of these has been 
modified to utilize slightly different techniques or different suture material, but all have the goal of correcting urethral hypermobility. A Cochrane review was performed and was up to date as of 2009 on this procedure. ${ }^{47}$ Ten trials were evaluated that contained 375 women who had needle suspension and 489 who had other procedures. The perioperative risk was similar comparing needle suspensions to retropubic suspension (seven trials), but the failure rate was increased 1 year and beyond (29\% vs $16 \%$ ). These procedures are rarely performed today due to their poor long-term success and the availability of other minimally invasive options.

\section{Laparoscopic colposuspension (22 RCTs, I systematic review)}

Was developed as a minimally invasive approach to female SUI and is performed in essentially the same way as a Burch procedure. A Cochrane review up to date as of 2009 reviewed 22 trials. $^{48}$ Ten articles compared laparoscopic with open Burch and found slightly worse results in the laparoscopy arms, but with fewer complications and shorter hospital stay. Eight studies compared the laparoscopic surgery to synthetic mid-urethral slings and found similar subjective cure, but better objective cure rates in the slings. With the shorter operative time and comparative simplicity of midurethral slings, laparoscopic Burch is currently rarely performed.

\section{Open abdominal retropubic suspensions (46 RCTs, I systematic review)}

These procedures are performed via a Pfannenstiel incision whose goal is to correct urethral hypermobility. The retropubic space is exposed and permanent sutures are placed in the anterior vaginal wall around the bladder neck and proximal urethra and are sutured to ileopectineal ligament in the case of a Burch colposuspension, or the bladder neck is suspended to the fibro cartillage of the symphysis in the Marshall-Marchetti-Krantz (MMK). The paravaginal repair or the vagina-obturator shelf repairs are variations of the Burch with more lateral placement of the sutures.

A Cochrane review published in 2009 reviewed 46 trials with 4738 women total. ${ }^{49}$ Overall they concluded that open retropubic suspensions are effective with 1 year $85 \%$ to $90 \%$ success and approximately $70 \% 5$-year dry rate. Compared with both needle suspensions and anterior repair (eight trials) there is a lower failure rate both in the shortand long-term.

Four small trials compared MMK with Burch with very limited data available. Overall in the short- and medium-term there were fewer surgical failures in the Burch group (23 vs $34 \%$ ).

Six trials compared retropubic suspension to pubovaginal sling (PVS), but only two of these utilized autologous fascia. ${ }^{50}$ Demirci and Yucel compared the pubovaginal sling and Burch colposuspension in 46 women with high valsalva leak point pressures $\left(>90 \mathrm{~cm} \mathrm{H}_{2} \mathrm{O}\right) \cdot{ }^{50,51}$ At 1 year there were no differences in complications; one patient in each group developed de novo detrusor over activity and on physical exam. In the Burch group only, there were two new significant pelvic organ prolapses and one surgical failure. Albo et al compared autologous PVS and Burch in a large, well designed trial that since the publication of the Cochrane review has undergone multiple sub analysis. ${ }^{44}$ This trial evaluated multiple outcomes both objectively and subjectively in 655 women who had relatively high val salva leak point pressures (average $<115 \mathrm{~cm} \mathrm{H}_{2} 0$ ). ${ }^{52}$ At 24 months the PVS group had greater overall (47\% vs $38 \% ; P<0.001)$ and stress specific $(66 \%$ vs $49 \% ; P<0.001)$ continence rates. The low success rates overall compared with prior trials are explained by the extremely rigorous definition of success utilized in this trial, which required all objective and subjective measures of continence to be met for a patient to be deemed cured. More women in the sling group had voiding dysfunction, urinary tract infections and all 20 women who required surgical revision due to urinary obstruction were in the PVS group. Women were 1.7 times as likely to need treatment for urgency incontinence after PVS, ${ }^{52}$ but sexual function improved and was not different between these groups. ${ }^{53}$ Only $3.5 \%$ of the recruited women had ISD with (Valsava Leak Point Pressure) $<60 \mathrm{~cm} \mathrm{H}_{2} \mathrm{O}$ so that these results cannot be extrapolated to that population.

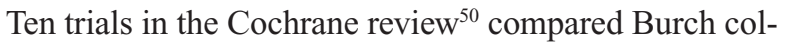
posuspension with tension-free vaginal tape (TVT), but most were of very small size and of short follow-up except one trial by Ward and Hilton in $2002 .{ }^{45}$ In all time periods these combined studies showed no significant difference in success rates between TVT and retropubic suspension. Operative time was shorter for the TVT as was hospital stay and cost was $25 \%$ less, but there is a slightly higher rate of vaginal or bladder perforation. Another systematic review was performed evaluating Burch and mid urethral slings and did find a slight advantage in cure rates with the latter (Table 1). ${ }^{54}$

In general, retropubic suspensions are very effective at correcting stress urinary incontinence in women with urethral hypermobility and higher leak point pressures. The risk of developing voiding dysfunction is very low after retropubic suspension, but there is an 8-fold risk of developing new 
or recurrent pelvic organ prolapse compared with any sling procedure. ${ }^{50}$ Given the morbidity of the open incision and the widespread belief, despite minimal evidence, that synthetic midurethral slings are equally effective, a Burch is often only performed in conjunction with a concomitant pelvic surgery such as abdominal sacrocolpopexy where the incision has already been made. ${ }^{55}$

\section{Pubovaginal slings (27 RCTs, 2 systematic reviews)}

These slings are placed via a combined abdominal Pfannenstiel incisions and vaginal incision. A strip of material is passed under the proximal urethra/bladder neck and tunneled up to be tied above the rectus fascia. The pubovaginal sling is designed to treat ISD, but is also effective at treating incontinence due to urethral hypermobility. The material utilized is typically abdominal rectus fascia harvested from the same incision, but autologous fascia latta from a separate incision is also used as have porcine dermis, cadaveric fascia, Teflon, Gore-Tex, Marlex, silastic, and Mersilene. A Cochrane review of traditional suburethral slings is newly available. ${ }^{56}$ In this review there were 26 trials with 2284 women included. The quality of these studies was only modest with small sample sizes, apart from the previously mentioned study by Albo et al, and follow-up was short ranging from 6 to 24 months.

The trials comparing Burch with autologous PVS showed superior cure rates at the expense of a higher voiding dysfunction and obstruction with the PVS and are discussed in the section above.

Twelve trials have compared PVS and midurethral slings in the review. Only short- and medium-term results are available, but at both time points there is no difference in patient reported incontinence between these slings.

Another systematic review performed recently evaluating only the biological PVS compared these to midurethral slings and found similar efficacy, but higher bladder injury rates after midurethral sling and higher rates of voiding dysfunction after PVS. ${ }^{56}$

One publication since that review compared porcine dermal slings (Pelvicol ${ }^{\circledR}$, Bard, Sweden) to autologous PVS and TVT in a RCT with 201 women. ${ }^{57}$ Incontinence was poorly defined in the treatment groups, but the Pelvicol slings had significantly worse outcomes than either the PVS or the TVT at 1 year with only a $22 \%$ dry rate (TVT $55 \%$, PVS $48 \% ; P=0.001$ ) suggesting that the material is not durable. Animal studies have explained this phenomenon and shown that in certain individuals Pelvicol is rapidly degraded. ${ }^{58}$ TVT and PVS had equivalent success, but PVS required a longer hospital stay and more patients required short-term self-catheterization. Unfortunately no RCTs have been performed comparing the PVS to midurethral slings in the treatment of ISD which is the primary indication for a PVS in the current treatment of SUI. ${ }^{59}$

\section{Summary}

Anterior repair and bladder neck needle suspensions are inferior surgical approaches to female SUI. Laparoscopic Burch is effective, but invasive when compared with minimally invasive synthetic slings and has similar success. Open retropubic Burch is effective in treating female SUI with high leak point pressures and urethral hypermobility, but does carry the risk of secondary pelvic organ prolapse. The pubovaginal sling is slightly more effective than Burch in this same population with an increased risk of voiding dysfunction. The primary utility of the PVS in treating ISD has not been evaluated in RCT. If a PVS is performed one should try to utilize autologous fascia. Level 1 evidence.

\section{Synthetic slings}

In 1990, Petros and Ulmsten described the integral theory. This theory proposes that a physiologic "backboard" is created through fixation of the middle region of the urethra to the pubic bone, via the pubourethral ligaments, and that this factor is critical to the continence mechanism. ${ }^{60}$

The integral theory of female urinary continence led to the development of the tension-free vaginal tape. ${ }^{61}$ This was introduced as a commercially available kit by Gynecare ${ }^{\circledR}$ Inc (Menlo Park, CA) and has ushered in a new era of stress incontinence treatment.

\section{Bottom up vs top-down retropubic midurethral slings}

The TVT sling is a narrow polypropylene strip, housed within a plastic sheath passed via trocars from a small vaginal incision to a suprapubic exit site at the skin's surface. This is described as a "bottom-to-top" technique. There have been modifications made to the Gynecare ${ }^{\circledR}$ design. SPARC ${ }^{\circledR}$ or (SupraPubic ARC system, American Medical Systems, Inc, Minnetonka, MN) is a similar polypropylene mesh, but this is passed in a "top-tobottom" fashion. A recent Cochrane review found three RCTs on patient-reported cure showing a significant difference in favor of "bottom-top" vs "top-bottom" at 12 months $(85 \%$ vs $77 \%$ ). The combined analysis of objective cure rate also favored "bottom-top" by a smaller margin, $92 \%$ vs $87 \% .{ }^{59}$

In the study with the longest follow-up, Tseng compared the efficacy and complication rates of TVT and SPARC in 
62 patients. They used a negative 1-hour pad test to define postoperative continence. They reported similar continence rates in the two arms (87\% vs $80.7 \%)$ and similar low complication rates. ${ }^{59}$

The largest published RCT $^{59}$ enrolled 147 patients randomized to TVT and 154 to SPARC. This study showed significantly higher subjective continence rates in the TVT arm (87.1\% vs $76.5 \%$ ). This was a well done study except for the very short follow-up (6-8 weeks). Combining all four studies: TVT outperformed SPARC in terms of subjective cure rate $(P=0.02)$ and objective cure rates $(P=0.005)$ according to any definition.

\section{Transobturator vs TVT-O}

The transobturator approach is another method of placement of a midurethral sling. ${ }^{61,62}$ Trocar placement is initiated just lateral to the labium majus and continued through the obturator foramen to a small vaginal incision. ${ }^{62}$ This approach was designed to minimize the risk of complications involving the enteric and vascular structures of the pelvis. A reversed "inside-out" approach also exists. ${ }^{63}$ Three RCTs directly compare "outside-in" to "inside-out" transobturator slings. ${ }^{63-66}$ These report equivalent cure rates both subjective and objective over the short- and medium-term follow-up (Table 1).

Latthe et al performed a meta-analysis of fourRCTS comparing the two different routes of transobturator tape. ${ }^{67}$ (Table 1) Follow-up ranged from 1 to 44 months. The evidence for the equivalent effectiveness of transobturator tape (TOT) and transvaginal tension free tape obturator (TVT-O) when compared with each other was established over the short-term. Bladder injuries and voiding difficulties seemed to be less with inside-out tapes on indirect comparison. Groin/ thigh pain (TVT-O, odds ratio [OR]: 8.05, 95\% confidence interval [CI]: 3.78-17.16) and vaginal injuries (TOT, OR: 5.82, CI: 1.85-18.3; TVT-O, OR: 1.69, CI: 0.73-3.91) were more common in the transobturator tapes. Authors recommended more long-term follow-up to establish the continued effectiveness of transobturator tapes. ${ }^{68}$

\section{Retropubic vs transobturator approach}

A Cochrane Review ${ }^{59}$ evaluated 24 trials that compared retropubic and transobturator midurethral slings. Subjective cure was reported in ten trials with a total of 1281 participants and showed no statistically significant difference between routes.

Sung et al in a review of six RCTs and 11 cohort studies in 2591 women showed no difference in subjective failure between the two routes $(5.7 \%$ for transobturator vs $7.8 \%$ for retropubic). They did note a lower risk of complications and de novo irritative voiding symptoms for the transobturator group.
They concluded that it would take RCT of 30,000 women to demonstrate superiority of one approach over the other. ${ }^{68}$

TVT-O and TVT were compared in 208 patients withvarying severity of SUI. At 1 year of follow-up, incontinence was cured in all mild SUI patients with both techniques. In patients with severe SUI, all were cured with TVT and $66 \%$ when treated with TVT-O $(P<0.001)$. They concluded that the severity of SUI is an important parameter that influences results after TVT-O and TVT, and could be used to guide surgeons in selecting the most effective intervention. ${ }^{69}$

In 2010, a multicenter, equivalence trial compared outcomes with retropubic and transobturator midurethral slings in women with stress urinary incontinence..$^{70}$ The primary outcome was treatment success at 12 months according to both objective (negative stress test, a negative pad test, and no retreatment) and subjective criteria (self-reported absence of symptoms, no leakage episodes recorded, and no retreatment). A total of 597 women were randomly assigned in the study and 95\% completed the 12-month assessment. Both approaches were considered equivalent (80.8\% retropubic slings vs $77.7 \%$ for the transobturator slings). The equivalence applies only to objective success. Equivalence between the two procedures could not be definitively shown for subjective success. There were differences in the complications associated with the two procedures with the transobturator sling more likely to have neurologic symptoms, such as leg weakness and groin numbness and the retropubic sling group members were more likely to have postoperative voiding dysfunction (Table 1).

\section{Patients with intrinsic sphincter deficiency (ISD)}

ISD represents the portion of SUI that is not due to a support defect or urethral hypermobility. Most of the published data have used a definition of an abdominal leak point pressure of $<60 \mathrm{~cm} \mathrm{H}_{2} \mathrm{O}$ or a maximal urethral closure pressure of $<20 \mathrm{~cm} \mathrm{H}_{2} \mathrm{O}$. Fortunately, one recent study has evaluated this difficult to treat condition. Schierlitz et al perfomed an RCT looking at the effectiveness of TVT compared with TOT in women with SUI and ISD. ${ }^{71} 164$ patients were enrolled in the study. On urodynamics 6 months after surgery, of the 138 patients tested, 14 of 67 (21\%) in the TVT group had persist entin continence compared with 32 of $71(45 \%)$ in the transobturator tape group (Fisher's exact test, $P=0.004$ ). Nine of the $67(13 \%)$ TOT group did request further surgical treatment to correct SUI compared with 0 of $71(0 \%)$ in the TVT group. Their conclusion was that, in the treatment of urodynamic stress incontinence with intrinsic sphincter deficiency, the insertion of TVT is the preferable surgical option (Table 1). 


\section{Mini-slings vs others}

The newest type of sling is the mini-sling, which requires only one incision, and no trocar passage is necessary outside the vagina. These slings are believed to be less invasive than the previously described midurethral slings. There are very limited data available on their safety and efficacy. ${ }^{62}$ These slings use self-fixating tips that provide immediate fixation into the obturator muscles. In January 2011, an RCT on a retropubic transvaginal tape vs mini-sling was performed. A total of 71 patients were randomized to both procedures. Subjective cure rates as well as dual channel subtraction cystometry and pressure flow studies at 6 months were used. The mini-sling was associated with a much higher rate of persistent stress urinary incontinence at 6 weeks and 6 months. The authors state that the mini-sling should be used with caution until more robust studies can be performed (Table 1). ${ }^{72}$

\section{Summary}

Midurethral slings are effective and safe for the treatment of stress urinary incontinence. TVT and SPARC are relatively similar retropubic approaches. Retropubic slings have a slight increase in voiding dysfunction compared withtransobturator routes, but have none of the thigh complications associated with obturator approaches. TVT appears to have better efficacy for more severe incontinence or ISD and little data exist for the mini-slings. Until more robust data are available, TVT and TOT remain the standard of care in patients undergoing surgical treatment for stress urinary incontinence. Level 1 evidence.

\section{Conclusion}

Many surgical options exist for SUI. Synthetic midurethral slings are minimally invasive, safe, and effective for women with high leak point pressures and hypermobility. There is robust evidence for both the retropubic and transoburator route with slightly different complications. What is missing among all these data is a comparison between surgical approaches for the treatment of intrinsic sphincter deficiency and low leak point pressure stress urinary incontinence, which is the most difficult type of incontinence to cure. What is needed is a large trial to compare surgical approaches such as the pubovaginal sling and the midurethral slings for incontinence in women with ISD and those women who have failed midurethral slings surgical procedures for stress urinary incontinence.

\section{Disclosure}

The authors declare no conflicts of interest in this work.

\section{References}

1. Haylen BT, de Ridder D, Freeman RM, et al. An International Urogynecological Association (IUGA)/International Continence Society (ICS) joint report on the terminology for female pelvic floor dysfunction. Neurourol Urodyn. 2010;29:4-20.

2. Berghmans L, Hendriks H. Conservative treatment of stress urinary incontinence in women: a systematic review of randomized clinical trials. Br J Urol. 1998;82:181-191.

3. Rapp D, Kobashi K. Outcomes following sling surgery: importance of definition of success. $J$ Urol. 2008;180:998-1002.

4. Wilson P. Adult Conservative Management. Health Publications. 2005;11:869-883.

5. Gormely E. Biofeedback and behavioral therapy for the management of stress urinary incontinence. Urol Clin North Am. 2002;29:551-557.

6. Subak L, Wing R, West D, Franklin F. Weight loss to treat urinary incontinence in overweight and obese women. $N$ Engl J Med. 2009;360:481-490.

7. Wing R, Smith D, Grady D, Creasman J, Richter H, Myers D. Effect of weight loss on urinary incontinence in overweight and obese women: results at 12 and 18 months. $J$ Urol. 2010;184:1005-1010.

8. Subak L, Richter H, Hunskaar S. Obesity and urinary incontinence: epidemiology and clinical research update. J Urol. 2009;182:S2-S7.

9. Cannon T, Chancellor M. Pharmacotherapy for stress urinary incontinence. Rev Urol. 2003;5:135-141.

10. Thor K, Katofiasc M. Effects of duloxetine, a combined serotonin and norepinephrine reuptake inhibitor, on central neural control of lower urinary tract function in the chloralose-anesthetized female cat. J Pharmacol Exp Ther. 1995;274:1014.

11. Dmochowski R, Miklos J, Norton P, Zinner N, Yalcin I, Bump R. Duloxetine versus placebo for the treatment of North American women with stress urinary incontinence. $J$ Urol. 2003;170:1259-1263.

12. Millard R, Moore K, Rencken R, et al. Duloxetine versus placebo in the treatment of stress urinary incontinence: A four continent randomized clinical trial. Br J Urol Int. 2004;93:311-318.

13. Corcos J, Collet JP, Shapiro S, et al. Multicenter randomized clinical trial comparing surgery and collagen injections for treatment of female stress urinary incontinence. Urology. 2005;65:898-904.

14. Klarskov N, Lose G. Urethral injection therapy: what is the mechanism of action? Neurourol Urodyn. 2008;27:789-792.

15. Bent AE, Foote J, Siegel S, Faerber G, Chao R, Gormley EA. Collagen implant for treating stress urinary incontinence in women with urethral hypermobility. J Urol. 2001;166:1354-1357.

16. TerMeulen PH, Berghmans LC, Nieman FH, van Kerrebroeck PE. Effects of Macroplastique implantation system for stress urinary incontinence and urethral hypermobility in women. Int Urogynecol J Pelvic Floor Dysfunct. 2009;2:177-183.

17. Maher CF, O'Reilly BA, Dwyer PL, Carey MP, Cornish A, Schluter P. Pubovaginal sling versus transurethral Macroplastique for stress urinary incontinence and intrinsic sphincter deficiency: a prospective randomised controlled trial. BJOG. 2005;112:797-801.

18. Malizia AAJr, Reiman HM, Myers RP, et al. Migration and granulomatous reaction after periurethral injection of polytef (Teflon). JAMA. 1984;251:3277-3281.

19. Dmochowski R, Herschorn S, Corcos J. Multicenter randomized controlled study to evaluate Uryx ${ }^{\circledR}$ urethral bulking agents in treating female stress urinary incontinence. Proceedings International Continence Society (ICS) 2002 (Heidelberg, Germany):187.

20. Kumar D, Kaufman M, Dmochowski R. Case reports: Periurethral bulking agents and presumed urethral diverticula. Int Urogynecol J Pelvic Floor Dysfunction. 2011. [Epub ahead of print].

21. Hurtado E, McCrery R, Appell R. The safety and efficacy of ethylene vinyl alcohol copolymer as an intra-urethral bulking agent in women with intrinsic urethral deficiency. Int Urogynecol J Pelvic Floor Dysfunct. 2007;18:869-873.

22. Lightner DJ, Fox J, Klingele C. Cystoscopic injections of dextranomer hyaluronic acid into proximal urethra for urethral incompetence: efficacy and adverse outcomes. Urology. 2010;75:1310-1314. 
23. Lightner D, Rovner E, Corcos J, et al. Randomized controlled multisite trial of injected bulking agents for women with intrinsic sphincter deficiency: mid-urethral injection of Zuidex via the Implacer versus proximal urethral injection of Contigencystoscopically. Urology. 2009;4:771-775.

24. Strasser H, Marksteiner R, Margreiter E, et al. Autologous myoblasts and fibroblasts versus collagen for treatment of stress urinary incontinence in women: a randomized controlled trial. Lancet. 2007;369:2179-2186.

25. Lee PE, Kung RC, Drutz HP. Periurethral autologous fat injection as treatment for female stress urinary incontinence: a randomized doubleblind controlled trial. J Urol. 2001;1:153-158.

26. Keegan PE, Atiemo K, Cody J, McClinton S, Pickard R. Periurethral injection therapy for urinary incontinence in women. Cochrane Database Syst Rev. 2007;3:CD003881.

27. Ghoniem G, Corcos J, Comiter C, Bernhard P, Westney OL, Herschorn S. Cross-linked polydimethylsiloxane injection for female stress urinary incontinence: results of a multicenter, randomized, controlled, single-blind study. J Urol. 2009;181:204-210.

28. Mayer RD, Dmochowski RR, Appell RA, et al. Multicenter prospective randomized 52-week trial of calcium hydroxylapatite versus bovine dermal collagen for treatment of stress urinary incontinence. Urology. 2007;69:876-880

29. Andersen RC. Long-term follow-up comparison of durasphere and contigen in the treatment of stress urinary incontinence. J Low Genit Tract Dis. 2002;6:239-243.

30. Koduri S, Goldberg RP, Kwon C, Dobrez DG, Sand PK. Factors influencing the long-term success of periurethral collagen therapy in the office. Int Urogynecol J Pelvic Floor Dysfunct. 2006;17:346-351.

31. Isom-Batz G, Zimmern PE. Collagen injection for female urinary incontinence after urethral or periurethral surgery. $J$ Urol. 2009;181:701-704.

32. Lai HH, Hurtado EA, Appell RA. Large urethral prolapse formation after calcium hydroxylapatite (Coaptite) injection. Int Urogynecol J Pelvic Floor Dysfunct. 2008;19:1315-1317.

33. Palma PC, Riccetto CL, Martins MH, et al. Massive prolapse of the urethral mucosa following periurethral injection of calcium hydroxylapatite for stress urinary incontinence. Int Urogynecol J Pelvic Floor Dysfunct. 2006;17:670-671.

34. terMeulen PH, Berghmans LC, van Kerrebroeck PE. Systematic review: efficacy of silicone microimplants (Macroplastique) therapy for stress urinary incontinence in adult women. Eur Urol. 2003;44:573-582.

35. Ghoniem G, Corcos J, Comiter C, Westney OL, Herschorn S. Durability of urethral bulking agent injection for female stress urinary incontinence: 2-year multicenter study results. J Urol. 2010;183:1444-1449.

36. Bano F, Barrington JW, Dyer R. Comparison between porcine dermal implant (Permacol) and silicone injection (Macroplastique) for urodynamic stress incontinence. Int Urogynecol J Pelvic Floor Dysfunct. 2005;16:147-150; discussion 150 .

37. Lightner D, Calvosa C, Andersen R, et al. A new injectable bulking agent for treatment of stress urinary incontinence: results of a multicenter, randomized, controlled, double-blind study of Durasphere. Urology. 2001;58:12-15.

38. Appell RA, Dmochowski RR, Herschorn S. Urethral injections for female stress incontinence. BJU Int. 2006;98(Suppl 1):27-30 discussion 31 .

39. Pannek J, Brands FH, Senge T. Particle migration after transurethral injection of carbon coated beads for stress urinary incontinence. J Urol. 2001;166:1350-1353.

40. Madjar S, Sharma AK, Waltzer WC, Frischer Z, Secrest CL. Periurethral mass formations following bulking agent injection for the treatment of urinary incontinence. J Urol. 2006;175:1408-1410.

41. Carr LK, Steele D, Steele S, Wagner D, Pruchnic R, Jankowski R, et al. 1-year follow-up of autologous muscle-derived stem cell injection pilot study to treat stress urinary incontinence. Int Urogynecol J Pelvic Floor Dysfunct. 2008;19:881-883.

42. Rapp DE, Kobashi KC. Outcomes following sling surgery: importance of definition of success. J Urol. 2008;180:998-1002.
43. Albo ME, Richter HE, Brubaker L, et al. Burch colposuspension versus fascial sling to reduce urinary stress incontinence. $N$ Engl J Med. 2007;24(356):2143-2155.

44. Ward K, Hilton P. United Kingdom and Ireland Tension-free Vaginal Tape Trial Group. Prospective multicentrerandomised trial of tensionfree vaginal tape and colposuspension as primary treatment for stress incontinence. BMJ. 2002;13(325):67.

45. Chartier-Kastler E, Van Kerrebroeck P, Olianas R, et al. Artificial urinary sphincter (AMS 800) implantation for women with intrinsic sphincter deficiency: a technique for insiders? BJU Int. 2011;107:1618-1626.

46. Glazener CM, Cooper K. Anterior vaginal repair for urinary incontinence in women. Cochrane Database Syst Rev. 2001;1 CD001755.

47. Glazener CM, Cooper K. Bladder neck needle suspension for urinary incontinence in women. Cochrane Database Syst Rev. 2004;2:CD003636.

48. Dean NM, Ellis G, Wilson PD, Herbison GP. Laparoscopic colposuspension for urinary incontinence in women. Cochrane Database Syst Rev. 2006;3:CD002239.

49. Lapitan MC, Cody JD, Grant A. Open retropubiccolposuspension for urinary incontinence in women. Cochrane Database Syst Rev. 2009;2:CD002912.

50. Demirci F, Yucel O. Comparison of pubovaginal sling and burchcolposuspension procedures in type I/II genuine stress incontinence. Arch Gynecol Obstet. 2001;265:190-194.

51. Nager CW, FitzGerald M, Kraus SR, et al. Urodynamic measures do not predict stress continence outcomes after surgery for stress urinary incontinence in selected women. J Urol. 2008;179:1470-1474.

52. Kenton $\mathrm{K}$, Richter $\mathrm{H}$, Litman $\mathrm{H}$, et al. Risk factors associated with urge incontinence after continence surgery. J Urol. 2009;182:2805-2809.

53. Brubaker L, Chiang S, Zyczynski H, et al. The impact of stress incontinence surgery on female sexual function. Am J Obstet Gynecol. 2009;200:562.e1-562.e7.

54. Novara G, Artibani W, Barber MD, et al. Updated systematic review and meta-analysis of the comparative data on colposuspensions, pubovaginal slings, and midurethral tapes in the surgical treatment of female stress urinary incontinence. Eur Urol. 2010;58:218-238.

55. Brubaker L, Cundiff G, Fine P, et al. Abdominal sacrocolpopexy with Burch colposuspension to reduce urinary stress incontinence. $N$ Engl J Med. 2006;354:1557-1566.

56. Rehman H, Bezerra CC, Bruschini H, Cody JD. Traditional suburethral sling operations for urinary incontinence in women. Cochrane Database Syst Rev. 2011;1:CD001754.

57. Guerrero KL, Emery SJ, Wareham K, Ismail S, Watkins A, Lucas MG. A randomised controlled trial comparing TVT, Pelvicol and autologous fascial slings for the treatment of stress urinary incontinence in women. BJOG. 2010;117:1493-1502.

58. Ozog Y, Konstantinovic M, Zheng F, et al. Porous acellular porcine dermal collagen implants to repair fascial defects in a rat model: biomechanical evaluation up to 180 days. Gyneco l Obstet Invest. 2009;68:205-212.

59. Ogah J, Cody JD, Rogerson L. Minimally invasive synthetic suburethral sling operations for stress urinary incontinence in women. Cochrane Database Sys Rev. 2009;4:CD006375.

60. Petros P, Ulmsten U. An integral theory of female urinary incontinence: experimental and clinical considerations. Acta Obstet Gynecol Scand. 1997;166:3-8.

61. Delorme E. Transobturator urethral suspension: mini-invasive procedure in the treatment of stress urinary incontinence in women. Prog Urol. 2001;11:1306-1313.

62. DeLeval J. Novel surgical technique for the treatment of female stress urinary incontinence: transobturator vaginal tape inside-out. Eur Urol. 2003;44:724-730.

63. Liapis A, Bakas P, Creatsas G. Monarc vs. TVT-O for the treatment of primary stress incontinence: a randomized study. Int Urogynecol J Pelvic Floor Dysfunction. 2008;19:185-190. 
64. Abdel-Fattah M, Ramsay I, Pringle S, Hardwick C, Ali H. Evaluation of transobturator tapes (E-TOT) study: randomized prospective singleblinded study comparing inside-out vsoutside-in transobturator tapes in management of urodynamic stress incontinence: short term outcomes. Eur J Obstet Gynecol Reprod Biol. 2010;149:106-111.

65. But I, Faganelji M. Complications and short term results of two different transobturator techniques for surgical treatment of women with urinary incontinence: a randomized study. Int Urogynecol J Pelvic Floor Dysfunct. 2008;19:857-861.

66. Takeyama M, Fukumoto Y, Noma M, Yamamoto K, Yamanaka M, Uesaka Y. A prospective study about trans-obturator tape procedures with the tape from the Gynecare TVT device and a C-shaped tunneling device. Available at: http://www.urotoday.com. Accessed June 1, 2010.

67. Latthe P, Foon R, Toozs-Hobson P. Transobturator and Retropubic tape procedures in stress urinary incontinence: a systematic review and meta-analysis of effectiveness and complications. BJOG. 2007;114:522-531.
68. Sung V, Schleinitz M, Rardin C, Ward R, Myers D. Comparison of retropubic vs transobturator approach to midurethral slings: a systematic review and meta-analysis. Am J Obstet Gynecol. 2009;21:342-347.68.

69. Araco F, Gravante G, Sorge R, et al. TVT-O vs TVT: a randomized trial in patients with different degrees of urinary stress incontinence. Int Urogynecol J. 2008;19:917-926.

70. Richter H, Albo M, Zyczynski H, et al. Retropubic versus transobturatormidurethral slings for stress incontinence. $N$ Engl JMed. 2010;362:2066-2076.

71. Schierlitz L, Dwyer L, Rosamilia A, et al. Effectiveness of tension-free vaginal tape compared with transobturator tape in women with stress urinary incontinence and intrinsic sphincter deficiency: a randomized controlled trial. Obstet Gynecol. 2008;112:1253-1261.

72. Kennelly M, Moore R, Nguyen J, Lukban J, Siegel S. Prospective evaluation of a single incision sling for stress urinary incontinence. J Urol. 2010;184:604-609.

\section{Publish your work in this journal}

The Open Access Journal of Urology is an international, peer-reviewed, open access journal publishing original research, reports, editorials, reviews and commentaries on all aspects of adult and pediatric urology in the clinic and laboratory including the following topics: Pathology, pathophysiology of urological disease; Investigation and treatment of

\section{Dovepress}

urological disease; Pharmacology of drugs used for the treatment of urological disease. The manuscript management system is completely online and includes a very quick and fair peer-review system, which is all easy to use. Visit http://www.dovepress.com/testimonials.php to read real quotes from published authors. 